The authors found that the effectiveness of a number of legal acts, aimed at the legal regulation of the culture of Ukrainian peasantry, the social development of the village and the revival of social cultural and material infrastructure, is low. The measures identified in them to overcome the crisis in the social sphere of the village have practically no proper mechanisms of implementation.

In view of this, the authors substantiate ways to improve the legal regulation for the preservation of the culture of Ukrainian peasantry. The key to preserving the peasantry as a carrier of the national culture of Ukrainian people, according to the authors, is an integrated solution to the peasant's social problems. This direction of state policy should be implemented through organizational, legal and socio-economic measures aimed at ensuring employment and reducing unemployment, expanding the network of cultural institutions in the countryside, improving the level of education of rural youth, the development of environmental awareness, education, legal and advisory activities.

Increasing the standard of living and life of Ukrainian peasantry, the authors associate with the need for its financial and economic support with the use of funds from the State and local budgets for the implementation of cultural and educational activities in the countryside, leisure activities with the promotion of agricultural producers. An important guarantee of preserving the culture of Ukrainian peasantry is to increase the legal responsibility of officials of state authorities and local self-government for making decisions that limit or violate peasants' rights.

Key words: agrarian reform, culture, ecological culture, employment of peasants, integrated development of rural areas, peasants, rural areas, social sphere of the village, sustainable development, village school.

DOI: $10.36695 / 2219-5521.1 .2020 .52$

УДК 349.6:342.57 (477)

\title{
К.А. КОЗмУляк
}

Катерина Андріївна Козмуляк, кандидат юридичних наук, асистент кафедри Чернівецького національного університету імені Юрія Федьковича* ORCID: 0000-0002-4989-3669

\section{ОКРЕМІ АСПЕКТИ РЕАЛІЗАЦІЇ ПРАВА ГРОМАДСЬКОСТІ НА УЧАСТЬ У СТРАТЕГІЧНІЙ ЕКОЛОГІЧНІЙ ОЦІНЦІ}

Постановка проблеми. Право громадськості на участь у прийнятті рішень, які можуть впливати на довкілля, передбачено рядом міжнародних актів: Декларацією Ріо-де-Жанейро щодо навколишнього середовища та розвитку (1992р.), Конвенцією про доступ до інформації, участь громадськості в процесі прийняття рішень та доступ до правосуддя з питань, що стосуються довкілля (1998р.) (далі - Орхуська конвенція), Директивами ЄС (Директива 2011/92/СС, Директива 2003/35/СС, Директива 2001/42/СС) тощо.

Так, Орхуська конвенція 1 визначає, що держави-учасниці повинні передбачити у національному законодавстві положення стосовно участі громадськості в процесі підготовки планів і програм, пов'язаних 3 навколишнім середовищем на принципах прозорості та справедливості. Близькі за змістом норми містяться й у Конвенції про оцінку впливу на навколишнє середовище у транскордонному контексті (далі - Конвенція ЕСПО) та Протоколі про стратегічну екологічну оцінку до Конвенції про оцінку впливу на навколишнє середовище у транскордонному контексті (далі - Протокол про СЕО).

3 метою імплементації у національне законодавство норм наведених вище міжнародних актів 12 жовтня 2018 р. був уведений в дію Закон України «Про стратегічну екологічну оцінку»² (далі - Закон про СЕО). Це привело до формування нових механізмів взаємодії громадськості з органами влади та місцевого самоврядування в процесі розробки та затвердження документів державного планування (далі - ДДП).

Аналіз останніх досліджень і публікацій. Питання участі громадськості у прийнятті рішень, які можуть впливати на довкілля на теренах України, досліджуються з 70-80-х pp. XX століття. Одними з перших про екологічні права громадськості та правовий статус громадських екологічних організацій почали говорити Ю.О. Вовк, О.С. Колбасов, В.Л. Мунтян, С.В. Размєтаєв, Ю.С. Шемшученко. Окремі аспекти забезпечення реалізації права на участь у прийнятті екологічно значимих рішень (право на доступ до екологічної інформації, правове регулювання громадської екологічної експертизи, право на участь у прийнятті рішень 3 питань, що стосуються довкілля та гарантії його реалізації) вивчали В.I. Андрейцев, А. Андрусевич, Г.І. Балюк, Ю.Л. Власенко, А.С. Євстігнєєв, Н.Р. Кобецька, М.В. Краснова, Н.Р. Малишева, Г.В. Мороз, О.В. Павлова, Е.В. Позняк, Т.О. Третяк та інші.

У зв'язку із прийняттям у 2018 р. Закону про СЕО виникла потреба в більш детальному дослідженні цієї процедури, можливостей участі громадськості та способів гарантування ії права бути почутою при ухваленні відповідних рішень. Питання особливостей стратегічної екологічної оцінки (далі - СЕО) ставали предметом дослідження, здебільшого, представників економічної та географічної наук. Правова складова цієї проблематики на сьогоднішній день залишається майже невивченою. Окремі дослідження проведені Д.О. Палеховим, С.М. Шершуном, С. Шутяк та ін. Проте вони, в основному, не враховують сучасного правового регулювання та носять фрагментарний характер.

(C) К.А. Козмуляк, 2020

* Kateryna Kozmuliak, Ph.D. in Law, Assistant Professor of Yuriy Fedkovych Chernivtsi National University 
Формулювання мети статті. Зважаючи на викладене, метою цієї статті є аналіз сучасного стану правового регулювання участі громадськості у процедурі стратегічної екологічної оцінки, вивчення механізму реалізації цього права та виявлення його можливих недоліків.

Виклад основного матеріалу. Протягом останніх років в Україні відбулись істотні зміни в правовому регулюванні доступу громадськості до участі у прийнятті рішень, які можуть впливати на довкілля.

Зокрема, Законом про СЕО визначено, що відповідна процедура повинна проводитись щодо ДДП, які стосуються сільського, лісового та рибного господарства, енергетики, промисловості, транспорту, поводження $з$ відходами, використання водних ресурсів, охорони довкілля, телекомунікацій, туризму, містобудування або землеустрою (схеми) та виконання яких передбачатиме реалізацію видів діяльності (або які містять види діяльності та об'єкти), щодо яких законодавством передбачено здійснення процедури оцінки впливу на довкілля, або які вимагають оцінки, зважаючи на ймовірні наслідки для територій та об'єктів природнозаповідного фонду та екологічної мережі, крім тих, що стосуються створення або розширення територій та об'єктів природно-заповідного фонду.

Громадськість в процесі проведення СЕО має право висловлювати свої пропозиції і зауваження на етапі обговорення заяви про визначення обсягу СЕО, під час обговорення проєкту ДДП і звіту про СЕО. При цьому думка громадськості не може бути залишена поза увагою: у довідці про громадське обговорення під час СЕО повинно бути відображено врахування, часткове врахування чи відхилення зауважень і пропозицій, які надійшли під час громадського обговорення.

Проте, незважаючи на певні позитивні зрушення в частині забезпечення участі громадськості в обговоренні проєктів ДДП, у цій сфері все ще наявний ряд недоліків і моментів, які потребують додаткового вивчення та врегулювання.

Перше, на що, на нашу думку, варто звернути увагу - це поняття громадськості, яке міститься у Законі про СЕО. Слід звернути увагу на те, що Орхуська конвенція, Протокол про СЕО, Директиви СС та українське законодавство використовують два схожі поняття «громадськість» та «зацікавлена громадськість».

Так, Орхуська конвенція застосовує одночасно поняття громадськості та зацікавленої громадськості, тобто тієї, на яку справляє або може справити вплив процес прийняття рішень 3 питань, що стосуються навколишнього середовища, або яка має зацікавленість цьому процесі, а також недержавні організації, які сприяють охороні навколишнього середовища. Протокол про СЕО та Директива 2001/42/СС Про оцінку впливу на стан довкілля окремих проєктів та програм говорять лише про громадськість, не звужуючи іiі до зацікавленості. Закон про СЕО, оперуючи поняттям громадськість, фактично розуміє їі як зацікавлену громадськість - одну чи більше фізичних або юридичних осіб, їх об'єднання, організації або групи, зареєстровані на території, на яку поширюється дія документа стратегічного планування.

На цю проблему звернуло увагу й Мінприроди. У Методичних рекомендаціях із здійснення стратегічної екологічної оцінки документів державного планування наголошено, що для цілей СЕО слід використовувати визначення громадськості, яке міститься у Протоколі про СЕО, а не у відповідному законі ${ }^{3}$.

Ведучи мову про залучення громадськості до участі в обговореннях в межах СЕО, варто зважати на те, що досить важливим фактором $є$ належне інформування про ДДП та його потенційний вплив на довкілля, час, місце і строки проведення громадських обговорень тощо. Для цього насамперед необхідно виявити коло осіб, які можуть бути зацікавлені в участі у громадських обговореннях в процесі СЕО. Методичні рекомендації із здійснення стратегічної екологічної оцінки документів державного планування (Додаток 7) пропонують наступний початковий перелік заінтересованих сторін: 1) органи виконавчої влади та органи місцевого самоврядування, які можуть бути зацікавлені в реалізації проєкту ДдП; 2) місцеве населення, яке може бути зачеплене екологічними і соціальними наслідками реалізації проєкту ДДП; 3) бізнес-організації, що проявляють інтерес до розвитку території або сфери, яку зачіпає проєкт ДДП; 4) громадські, наукові, культурні, освітні, релігійні організації та установи, лідери та активісти різних груп і рухів, які можуть внести вклад в реалізацію проєкту ДДП та заінтересовані в обговоренні їі екологічних та соціальних аспектів.

Не менш важливим моментом вважаємо й безпосереднє залучення громадськості до участі в обговоренні проєктів ДДП. За результатами аналізу довідок про громадське обговорення в процесі СЕО можемо зробити висновок про те, що громадськість не приділяє достатньої уваги обговоренню програм, планів або конкретних проєктів. Це, на нашу думку, може бути спричинено рядом обставин. Наприклад, деякі особи можуть мати бажання, але не мати можливості брати участь в обговоренні (наприклад, групи з обмеженими можливостями участі: особи похилого віку, особи з фізичними вадами тощо). Інші можуть мати можливість, але не мати бажання брати участь (наприклад, особи, які мають негативний досвід, не мають часу або ті, які вважають, що участь не принесе їм користі) ${ }^{4}$. Крім цього, представники громадськості можуть стикатися 3 труднощами при отриманні інформації про те, чи зачіпає план, програма або конкретний проєкт їх інтереси. Оприлюднена інформація може виявитися недостатньою або опублікованою в засобах масової інформації, які не мають належного охоплення відповідної цільової групи.

Варто зазначити, що в частині, що стосується інформування під час CEO, законодавство містить лише мінімальні вимоги. Зокрема, на замовника СЕО (орган виконавчої влади або орган місцевого самоврядування, який є відповідальним за розроблення ДДП), покладено обов'язок оприлюднити на своєму офіційному веб-сайті заяву про визначення обсягу CEO, проєкт ДДП та звіт про СЕО, а також опублікувати повідомлення про це не менш як у двох друкованих ЗМІ, визначених замовником.

Деякою мірою деталізує положення Закону про СЕО Порядок залучення громадськості до обговорення питань щодо прийняття рішень, які можуть впливати на довкілля, затверджений постановою Кабінету міністрів України від 29 червня 2011 р. № 7715. Зокрема, цим нормативним актом встановлено, що відповідне повідомлення повинно бути оприлюднено у спосіб, що гарантує доведення інформації до відома мешканців відпо- 
відної адміністративно-територіальної одиниці або членів відповідної територіальної громади та інших заінтересованих осіб. Повідомлення (оголошення) про проведення громадських слухань може додатково надсилатися потенційним учасникам слухань із використанням засобів поштового та електронного зв'язку, розміщуватися у громадських місцях, інформаційних центрах та поширюватися через представницькі, консультативні й дорадчі органи. При цьому привертає увагу спосіб формулювання норми про додаткові форми інформування громадськості, яка носить не імперативний, а швидше диспозитивний рекомендаційний характер.

На нашу думку, окреслений перелік заходів, віднесених до обов'язкових, не здатен повною мірою забезпечити ефективне інформування громадськості та залучення іï до обговорення. У літературі та аналітичних оглядах звертають увагу на те, що інформування, яке дійсно має на меті залучення широких верств населення до обговорення проєкту, повинно включати широку інформаційну кампанію в соціальних мережах, а також залучення журналістів до висвітлення теми на радіо та телебаченні.

Водночас детальне врегулювання на нормативному рівні способів інформування громадськості про проєкти ДДП, на нашу думку, несе певні ризики. Зокрема, така норма може призвести до невиправданих витрат замовника у випадку, коли, наприклад, відомо, що використання друкованих засобів масової інформації на відповідній території є неефективним, оскільки місцеві мешканці не читають місцевих газет. Разом із тим, якщо в силу особливостей місцевої громади друковані засоби масової інформації є найбільш дієвим засобом доведення інформації до відома громадськості, сумнівною стає доцільність застосування інших способів оприлюднення повідомлень і відомостей в процесі СЕО. Це ж стосується й інформування громадськості, яке виходить за межі рамок, визначених чинним законодавством (робота з журналістами, просвітницькі заходи, поширення інформації через соціальні мережі). Зважаючи на те, що інформування громадськості про проєкти ДДП здійснюється за рахунок замовника, покладення на нього необгрунтованих фінансових навантажень може мати негативні наслідки, зокрема, для місцевих бюджетів.

Наступне, на що слід звернути увагу - це саме опрацювання пропозицій і зауважень громадськості, яка взяла участь у обговоренні проєкту планованої діяльності, плану чи програми. Закон про СЕО містить норму, відповідно до якої зауваження та пропозиції, що надійшли під час громадського обговорення, мають бути враховані, частково враховані або обгрунтовано відхилені. Відомості про це вказуються у довідці про громадське обговорення в процесі СЕО. Однак критерії врахування, часткового врахування або відхилення пропозицій і зауважень громадськості на сьогоднішній день відсутні.

Беручи до уваги окреслені вище особливості правового регулювання, вважаємо за доцільне проаналізувати гарантії реалізації та способи захисту права громадськості на участь у СЕО. Однією з таких гарантій $\epsilon$ визначена Законом України «Про охорону навколишнього природного середовища» 6 невідворотність юридичної відповідальності за правопорушення у досліджуваній сфері (абз. 17 ч. 2 ст. 68). Однак вказівки на конкретні заходи впливу на порушників закон не містить, а лише відзначає, що винні особи притягаються до дисциплінарної, адміністративної, цивільної чи кримінальної відповідальності. Натомість у Законі про СЕО взагалі відсутні положення про можливість притягнення до юридичної відповідальності. Кодекс України про адміністративні правопорушення (далі - КУПАП) та Кримінальний кодекс України також не говорять про відповідальність за правопорушення у сфері СЕО.

Поряд із притягненням винних до юридичної відповідальності важливого значення в контексті гарантій досліджуваного права набуває й можливість оскарження рішень, прийнятих за результатами СЕО, зокрема, у випадку ігнорування пропозицій і зауважень громадськості або коли громадськість не була належним чином повідомлена про ДДП. Зазначимо, що Закон про СЕО порядок оспорювання рішення, дій або бездіяльності уповноваженого суб'єкта не врегульовує взагалі (хоча, як свідчить судова практика, такі рішення досить часто підлягають оскарженню).

Не ставлячи під сумнів важливості права на судове оскарження рішень, дій та бездіяльності уповноважених суб'єктів зауважимо, що, на нашу думку, оспорювати та скасовувати вже прийняте рішення далеко не так ефективно, як домовитись про прийнятний варіант для всіх сторін процесу до його ухвалення. Відтак, вважаємо, що узгодження проєкту ДДП із пропозиціями та зауваженнями громадськості повинно відбуватися не пізніше, ніж на етапі їх громадського обговорення. Видається, що саме про це йдеться у ч. 4 ст. 6 Орхуської конвенції: «Кожна зі Сторін забезпечує участь громадськості вже на ранньому етапі, коли є всі можливості для розгляду різних варіантів і коли участь громадськості може бути найефективнішою».

Ведучи мову про громадське обговорення в процесі CEO, слід враховувати те, що розробка окремих державних програм нерідко призводить до виникнення конфліктних ситуацій. Практично будь-який конфлікт у цій сфері включає в себе протистояння приватних і публічних інтересів. Його сторонами, як правило, $\epsilon$ представники громадськості, суб'єкти господарювання, а також органи влади або місцевого самоврядування. Очевидним є і явний дисбаланс сил сторін конфлікту. Досить часто в таких конфліктах простежується проблема так званої «екологічної нерівності»7. Коли більш впливові або багатші суб'єкти підтримують розміщення об'єктів, які можуть чинити вплив на довкілля в місцях, де проживають бідніші особи або представники національних меншин.

Наука і практика розробили низку способів і методів урегулювання подібних конфліктів. Одним із найбільш ефективних із них вважається медіація. Ця процедура в Україні поки не набула достатнього поширення, хоча ряд нормативних актів уже передбачає можливість ії застосування.

Під медіацією розуміють неформалізовану, але чітко структуровану процедуру врегулювання спору за участі нейтрального посередника (медіатора), який підтримує сторони в досягненні ними взаємовигідного рішення. До основних принципів, на яких базується медіація, належать: добровільність участі у процедурі (сторони за власним бажанням можуть розпочати, припинити медіацію або продовжити їі), конфіденційність (усе, що відбувається під час медіації, залишається в таємниці), рівність сторін. 
Робота медіатора спрямована на те, щоб спонукати сторони відійти від позиційних переговорів, де вони займають позицію, від якої відходять неохоче, до принципових переговорів (переговорів за інтересами) 8 . Медіаційний процес допомагає сторонам виявити сильні й слабкі сторони як своєї позиції, так і позиції опонента, оцінити потенційні ризики, виявити спільні інтереси і цілі, сформулювати взаємоприйнятне рішення. При цьому медіатор, ведучи переговори, повинен поставити інтереси всіх сторін на один рівень. Таке розширення можливостей «слабких зацікавлених сторін» та створення балансу сил є безумовним плюсом застосування медіації для вирішення конфліктів, що виникають при розробці документів державного планування9. Водночас не будь-який конфлікт може бути врегульований за допомогою медіації. Визначають наступні критерії медіабельності конфліктів у досліджуваній нами сфері 10 : 1) сторони в переговорах зайшли в глухий кут або є чітке розуміння, що конфлікту не уникнути; 2) сторони зацікавлені та готові брати участь у медіації; 3) сторони та їх представники наділені необхідною «гнучкістю» і повноваженнями у прийнятті рішень; 4) сторони володіють засобами, необхідними для реалізації досягнутої домовленості.

Попри очевидні переваги, існує і ряд проблем у запровадженні медіації в реаліях сьогодення. Зокрема, в Україні досі відсутнє чітке правове регулювання у цій сфері. Наявний лише проєкт закону про медіацію, навколо якого точаться численні дискусії. Крім цього, для належного правового регулювання медіації в досліджуваній сфері необхідним, на нашу думку, є вирішення наступних питань: 1) на якому етапі СЕО може і повинна бути застосована медіація; 2) чи може бути визнана медіація в окремих випадках обов'язковою до застосування; 3) якими мають бути строки проведення медіаційної процедури?

Висновки. За результатами проведеного дослідження можемо сформулювати наступні висновки та рекомендації щодо удосконалення законодавства України у сфері реалізації права громадськості на участь у стратегічній екологічній оцінці.

1. Стосовно меж правового регулювання способів повідомлення громадськості про проєкти ДДП. Закон України «Про стратегічну екологічну оцінку» в цій частині потребує деталізації. Адже розміщення повідомлення про проєкт ДДП лише на сайті уповноваженого органу та в двох ЗМІ на вибір заявника, на нашу думку, не забезпечує належного інформування широкої громадськості. Крім цього, вважаємо за доцільне доповнити Закон про СЕО положенням про відповідальність за неналежне інформування громадськості.

2. Доопрацювання потребують і положення, спрямовані на гарантування та захист прав громадськості в процесі СЕО. Зокрема, це стосується притягнення до юридичної відповідальності за порушення порядку проведення CEO, а також за неналежне інформування громадськості під час цих процедур. Вважаємо за необхідне доповнити КУпАП відповідними складами правопорушень у сфері СЕО.

3. Стосовно запровадження медіації в СЕО. На нашу думку, вона може бути застосована на будь-якому етапі CEО. Якщо очевидним $є$ те, що конфлікту не уникнути, медіація повинна бути застосована якомога раніше. Адже, як свідчить практика, задля максимально можливого врахування інтересів усіх зацікавлених сторін, залучення громадськості до діалогу повинно відбуватися з самого початку процесу планування (коли ідеї можуть обговорюватися, оскаржуватись та доопрацьовуватись) і тривати аж до прийняття ДДП.

Що стосується обов'язковості медіації. Вважаємо прийнятним у порядку проведення громадських слухань передбачити норму, за якою організатор таких слухань у випадку наявності принципових суперечностей щодо ДДП обов' язково повинен запропонувати сторонам врегулювати спір за допомогою медіації. Припускаємо, що це дозволить уникнути численних позовів, спрямованих на скасування рішення, прийнятого за результатами СЕО.

Важливим $є$ також чітке визначення часових меж проведення медіаційної процедури. На нашу думку, вони мають бути достатніми для належної підготовки, проведення конструктивних переговорів та прийняття узгодженого рішення. При цьому строки не повинні бути надто тривалими, щоб суттєво не гальмувати розробку ДДП. Вважаємо, що з метою запобігання зловживанням та затягуванню СЕО медіація не повинна перевищувати 60 днів, з можливістю продовження, у випадку необхідності, до 120 днів.

1 Конвенція про доступ до інформації, участь громадськості в процесі прийняття рішень та доступ до правосуддя 3 питань, що стосуються довкілля від 25 червня 1998 p. URL: https://zakon.rada.gov.ua/laws/show/994_015/conv

2 Про стратегічну екологічну оцінку: Закон України від 20 березня 2018 р. Офіційний вісник України. 2018. № 32. Cт. 1110. URL: https://zakon.rada.gov.ua/laws/show/2354-19

3 Методичні рекомендації із здійснення стратегічної екологічної оцінки документів державного планування: наказ Мінприроди від 10 серпня 2018 р. № 296. URL: https://menr.gov.ua/files/docs/nakazy/2018/nakaz_296.pdf

4 Рекомендации о надлежащей практике участия общественности в стратегической экологической оценке. Европейская Экономическая Комиссия. URL: https://www.unece.org/fileadmin/DAM/env/eia/Publications/2016/Good_Practice_Recommenda tions_on_Public_Participation_in_Strategic_Environmental_Assessment/1514366_R_web_ESPOO.pdf

5 Порядок залучення громадськості до обговорення питань щодо прийняття рішень, які можуть впливати на довкілля: постанова Кабінету міністрів України № 771 від 29 червня 2011 р. Офіиійний вісник Украӥни. 2011. № 55. Ст. 2210. URL: https://zakon. rada.gov.ua/laws/show/771-2011-\%D0\%BF

6 Про охорону навколишнього природного середовища: Закон України від 25 червня 1991 р. Відомості Верховної Ради Украӥни. 1991. № 41. Ст. 546. URL: https://zakon.rada.gov.ua/laws/show/1264-12/conv

7 Андрій Андрусевич Про екологічне верховенство права URL: https://www.prostir.ua/?news=andrij-andrusevych-pro-ekolo hichnu-svidomist-ukrajintsiv-aktyvnist-hromadskyh-orhanizatsij-ta-ekolohichni-reformy

${ }^{8}$ Henry Brooke. The role of Mediation in Planning and Environmental Disputes. URL: https://sirhenrybrooke.me/2015/12/16/ the-role-of-mediation-in-planning-and-environmental-disputes/\#content

9 Ursula Caser, Cátia Marques Cebola. Environmental mediation: an instrument for collaborative decision making in territorial planning. Finisterra. Revista Portuguesa de Geografia. LII. № 104. 2017. P. 113. DOI: https://doi.org/10.18055/Finis6969 
10 Christopher Wood. Environmental impact assessment: a comparative review. - $2^{\text {nd }}$ ed. Routledge. 2013. P. 277; Neil G. Sipe (1998) An Empirical Analysis of Environmental Mediation. Journal of the American Planning Association. 64:3. pp. $275-285$. DOI: https://doi.org/10.1080/01944369808975985

\section{Резюме}

Козмуляк К.А. Окремі аспекти реалізації права громадськості на участь у стратегічній екологічній оцінці.

У статті проведено аналіз сучасного стану правового регулювання реалізації права громадськості на участь у стратегічній екологічній оцінці в Україні. Зроблено висновок, що основні проблеми в цій сфері виникають при залученні громадськості до обговорення, іiї належному інформуванні про відповідні процедури, а також при захисті прав останньої, у випадку їх порушення. Проаналізовано можливості притягнення до юридичної відповідальності за порушення вимог законодавства у сфері CEO. Окрема увага у роботі приділена медіації як способу врегулювання потенційних конфліктів. Сформульовано висновок про те, що названа процедура може бути застосована на будь-якому етапі CEO, запропоновано орієнтовні максимальні строки iii проведення.

Ключові слова: екологічні права, стратегічна екологічна оцінка, громадськість, громадські слухання, рішення, які можуть впливати на довкілля, конфлікт, медіація.

\section{Резюме} оценке.

Козмуляк E.A. Отдельные аспекты реализации права общественности на участие в стратегической экологической

В статье проведен анализ современного состояния правового регулирования участия общественности в стратегической экологической оценке в Украине. Сделан вывод, что основные проблемы в этой сфере возникают при привлечении общественности к обсуждению, ее надлежащем информировании о соответствующих процедурах, а также при защите прав последней в случае их нарушения. Проанализированы возможности привлечения к юридической ответственности за нарушение требований законодательства в сфере СЭО. Особое внимание в работе уделено медиации как способу урегулирования потенциальных конфликтов. Сформулирован вывод о том, что названная процедура может быть применена на любом этапе СЭО, предложены ориентировочные максимальные сроки ее проведения.

Ключевые слова: экологические права, стратегическая экологическая оценка, общественность, общественные слушания, экологически значимые решения, конфликт, медиация.

\section{Summary} ment.

Kateryna Kozmuliak. Some aspects of the realization of the public's right to participate in strategic environmental assess-

The aim of this article is to analyse the current state of legal regulation of public participation in the strategic environmental assessment (hereinafter - SEA) procedure, to study the mechanism for exercising this right and to identify its possible shortcomings.

The article concludes that there are some problems that do not properly exercise the public's right to participate in SEA. They are the follows: 1) the procedure of public discussion during the SEA needs to be improved in terms of informing the public; 2) the mechanism of guaranteeing and protecting the right to participate in SEA is imperfect and does not provide adequate protection in the event of a violation of this right.

On author's opinion the list of mandatory measures, defined in the SEA legislation of Ukraine, does not fully ensure the effective informing of the public and involving it in the discussion of state planning documents. The information that really aims to engage the general public should include not only print media but also a broad social media campaign, engaging journalists in radio and television coverage. However, there is a risk that detailed regulation at the legal level of ways of informing the public in this area would lead to unjustified costs of SEA customer's budgets.

Particular attentionin the article is paid to the study of ways of protecting the rights of the public in case of improper informing or neglect of public comments during the SEA. It is concluded that ways of protection of the investigated right may be the next: to challenge the decisions, actions or omissions of participants of the SEA process and to bring to justice for the violation of the requirements of the SEA legislation. However, The SEA Act makes no mention of such mechanisms. The Code of Administrative Offenses and the Criminal Code of Ukraine also do not contain the relevant types of offenses. The author considers this situation unacceptable and proposes to supplement the Code of Ukraine of Administrative Offenses with the relevant offenses in the field of SEA.

The article concludes that mediation is an important mechanism for resolving conflicts that may arise in the conduct of SEA. This procedure may be applied at any stage of SEA. If it is obvious that conflict will not be avoided, mediation should be applied as soon as possible. At the same time, its terms should not be too long, so as not to paralyze the development of draft state planning document.

Key words: ecological rights, strategic environmental assessment, public, public hearings, decision-making in environmental matters, conflict, mediation. 